\title{
Correlation among Cost of Capital, Book Values and Shares Prices: The Case of Kuwait Listed Companies
}

\author{
Mohamad H. Atyeh and Wael Al-Rashed
}

\begin{abstract}
The objective of this research is to examine the degree of correlation between the cost of capital from a side and shares market prices and their book values at Kuwait Stock Exchange from the other side. The notion here is that correlation of some sort is transpiring which could affect published financial information and decision making at large. The basic equity valuation model used in the study is the one developed originally by Ohlson (1995), which relates the firm's equity market value to its book value adjusted for abnormal earnings. A sample of Kuwaiti firms listed on Kuwait stock exchange is used for testing this presumption for the period between 2005 and 2011. The results showed a negative correlation between the cost of capital versus companies' book value on one side, and the cost of capital versus companies' market value on the other side.
\end{abstract}

Index Terms-Book value, market value, market capitalization, cost of capital, Kuwait stock exchange (KSE), capital asset pricing model (CAPM).

\section{INTRODUCTION}

After the recent financial crises that the world has witnessed in year 2008, a gap has become obvious between the estimated fair value of most listed companies and its actual values that are reflected by its financial statements. Hence and to investigate this fact on the Kuwaiti listed companies, our research is an attempt to test the degree of correlation between the cost of capital and the market value. In other word, the effect of the cost of capital on firms book value. This test is based on the equity valuation model, which was developed originally by Ohlson (1995).

Results will assist in understanding the viability of the share prices to companies operations reflected by the amount of leverage it holds, in addition to checking for any market feedback to the financial performance of companies after commencing operations.

The research project covers samples of the companies listed on Kuwait Stock Exchange (KSE) for the period between 2005 and 2011 and represent most sectors in KSE totaling to twenty-three companies.

\section{RESEARCH IMPORTANCE}

Results certainly assist decision makers in setting policies applicable for the determination of disclosure requirements. Both abnormal earnings per share and book value are useful equity market value indicators, which in turn are affected by

Manuscript received August 27, 2013; revised November 5, 2013.

Mohamad H. Atyeh is with the Australian College of Kuwait (ACK), Kuwait (e-mail: m.atyeh@ack.edu.kw). interest rates and the cost of finance on the company. This research is to measure the incremental value information content of published data. Currently, book value is more important to investors in determining fair prices that are affected by abnormal earnings or abnormal operating cash flow.

\section{LITERATURE REVIEW}

There are significant amount of research conducted on corporate finance as pertinent to stock prices and the cost of capital. Correlation coefficient here is a statistical method used to examine the degree of strength between the two variables.

Ohlson (1995) provided a research paper explains the relationship of the firm's equity value with its book value and market value. Reference [1] declared that Ohlson model has significantly improved the implications of the empirical research in that field. Reference [2] citied that "Ohlson (1995) and Feltham and Ohlson (1995) papers are landmark works in financial accounting". Lundholm added "Ohlson and Feltham present us with a very crisp yet descriptive representation of the accounting and valuation process" [2].

As per [3], Ohlson model provided better prices of stocks compared to the other discounted cash flows and dividends approaches. In addition he stated "The Ohlson (1995) and Feltham and Ohlson (1995) studies stand among the most important developments in capital markets research in the last several years. The studies provide a foundation for redefining the appropriate objective of [valuation] research". Reference [4] added that this model provides a complete approach to valuation comparing to other valuation approaches.

A study conducted by [5] using Ohlson (1995) model showed that the value relevance has decreased in New York Stock Exchange for the period tested from 1978 to 1997. The reason behind this study was to examine the relevancy between the book value and dividends from a side and the book value and earnings from the other side.

In 2001, Ohlson model have attracted many researchers such as [6], [7] in addition to [8]. The previous tests took place in Sweden using the cross section data, USA using the same previous approach and in USA also using the time serious period respectively. All tests results show that this model is applicable and efficient.

An unpublished research conducted in 2004 by [9] at the University of Cape Town applying Ohlson (1995) model on the industrial sector of Johannesburg Security Exchange for the period between 1993 and 2002. The research examined the book value and earnings without considering the 
dividends. The research concluded that the value relevance across Johannesburg has increased across the examined period.

Reference [10] have used 21 listed companies from Tehran Stock Exchange for a period of fifteen years and reviewed seven linear information models. The research resulted that the Ohlson model (1995) is the best among the other models reviewed in terms of the abnormal earning forecasting.

One of the important researches was conducted by [11] using the Ohlson model. Vazquez described it as the model that explains the market value of the company as a linear regression of its book value, abnormal earnings with the other variable information. Reference [12] stated that "The Ohlson (1995) valuation model made a hit in the market-based research; it motivated the adoption of the historical price model in the value relevance studies".

There are a number of studies, which were conducted using Ohlson (1995) valuation model, which have examined the company's earnings and book value. Reference [13] examined the degree of correlation of the financial variables and the underlying stock prices in the Mexican market. The results of [13] test show that the earnings and book value are correlated. In their study, [14] have investigated the relationship of earnings and book values to the stock prices in six countries from Asia. [14] argued that this kind of test would be useful for settling the international accounting standards.

Another study conducted by [15] investigated the changes in the relevance of book values and earnings over forty years for the period from 1953 to 1993. Results showed an increase in the combined value of earnings and book values over the study period.

In his research [16] commented on Ohlson (1995) model and mentioned that the empirical studies could not find any superiority of Ohlson (1995) over the discounted cash flow method. In his study, he relied on [1] which concluded that using the Ohlson model "provides only minor improvements over existing attempts to implement the dividend-discounted model by capitalizing short-term earnings forecasts in perpetuity". While [17] tested Ohlson Model to check for the treatment of the other information, seemed to be generally supporting information dynamics of Ohlson model.

Hence and based on the studies mentioned above, it would be reasonable to use the same model of Ohlson (1995) in testing the existence of correlation on Kuwait stock exchange companies between the share prices from a side and the book value and earnings from the other side.

\section{Methodology}

This paper aims at examining the effect of cost of capital on share prices of Kuwaiti listed companies. The model is based on the cost of capital as well as the book value after adjusting the abnormal earnings. Ohlson (1995) basic equity valuation model is used in to measure the degree of correlation as represented by the following equation:

$$
P t=b v t+\alpha 1 \chi^{\mathrm{a}} t+\alpha 2 v t
$$

where
$P t$ is the market value of the firm's share equity, time t.

$b v t$ is the book value of the firm's share equity, time $\mathrm{t}$.

$\chi^{a} t$ is the abnormal earning per firm's share during the year $\mathrm{t}$.

$v t$ is a non-accounting value relevant information, time $\mathrm{t}$.

$\alpha 1, \alpha 2$, are coefficients taking values that are a function of the linear information dynamics models and the risk free rate for the firm.

As for estimating the discount rate and cost of capital (defined as WACC which is the weighted average cost of capital), most researches used a discount rate of $12 \%$. Yet, few of them used specific discount rate was calculated for each single firm for each year [18].

On the other hand, the widely recognized technique CAPM (Capital Asset Pricing Model) is frequently used as discount rate as per [19] which can be determined by the following formula:

$$
D R=R f r+(\beta \times R p)
$$

where

$D R$ is the Discount Rate

$R f r$ is the Risk Free Rate

$\beta$ is the company Specific Risk

$R p$ is the Risk Premium of the Country

Hence, the Weighted Average Cost of Capital (WACC) would be as follows:

$$
W A C C=D R \times E /(D+E)+I \times D /(D+E)
$$

where

$D R$ is the discount rate

$D$ is the debt for each firm

$E$ is the equity for each firm

$I$ is the interest rate

Note: No tax was assumed since Kuwait is a tax-free country

\section{SAMPle SElection AND DATA}

The study uses a sample from the companies listed on Kuwait Stock Exchange (KSE). Twenty-three companies were included from different sectors, noting that KSE new classification consists of fifteen sectors. Hence, companies were taken from the different sectors to end up with twenty-three companies as detailed in Table I.

TABLE I: DATA USED

\begin{tabular}{lc}
\hline \hline KSE Sectors & No. of Companies Used \\
\hline Banking & 2 \\
\hline Consumer Goods & 2 \\
\hline Consumer Services & 2 \\
\hline Insurance & 2 \\
\hline Financial Services \& Invest. & 3 \\
\hline Industries & 2 \\
\hline Telecommunications & 2 \\
\hline Technology & 2 \\
\hline Oil and Gas & 2 \\
\hline Healthcare & 2 \\
\hline Real Estate & 2 \\
\hline Total & 23 \\
\hline \hline
\end{tabular}


Data were collected for the period between 2005, while book value per share was calculated based on the company's yearend audited financial statements. Companies included in the test have a non-negative book value during the studied years. Share prices included in the study are the yearly closing price for every company from the Kuwait stock exchange probably due to the fact that companies included in the test are active in Kuwait Stock Exchange (KSE).

As per used risk free rate, researchers adopted the average yield on long term treasury bonds for each year included in the test. While, risk premium used as per Damodaran's figures for Kuwait risk premium for each year included in the test.

\section{DESCRIPTIVE STATISTICS}

Table II reports summary statistics for variables used in the analysis reported in the columns. MVS is the share price (the market value of the company's share) on the last traded day of each year. BVS is the book value of company's equity as of December yearend financial statements. WACC is the company's weighted average cost of capital calculated based on the discount rate of each company (cost of equity) and cost of debt as explained in the previous equations.

TABLE II: DATA DESCRIPTIVE STATISTICS

\begin{tabular}{lccc}
\hline & $M V S$ & $B V S$ & WACC \\
\hline Mean & 603.11 & 1932.53 & 0.103 \\
\hline Median & 377.00 & 1059.17 & 0.100 \\
\hline Standard Deviation & 628.16 & 1682.05 & 0.020 \\
\hline Minimum & 94.71 & 417.14 & 0.074 \\
\hline Maximum & 2134.29 & 5901.00 & 0.145 \\
\hline Count & 23 & 23 & 23 \\
\hline \hline
\end{tabular}

The study ended up with 23 observations for each variable distributed over seven years for twenty three companies listed on Kuwait Stock Exchange (KSE) from different sectors.

\section{RESULTS AND DISCUSSION}

The data covered in the study includes companies from different sectors in Kuwait stock exchange with a total book value of nearly KD 6.6 billion. The market capitalization (MCAP) of the companies used in the test is estimated at KD 12 billion which represent around $40 \%$ of the total market MCAP of the KSE which is around 30 billion at the time of the study.

The test results show a negative correlation between the cost of capital and the book values of Kuwait stock exchange companies used in the test as indicated in Table III.

TABLE III: BVS \& WACC RESULTS

\begin{tabular}{lcc}
\hline & $B V S$ & WACC \\
\hline$B V S$ & 1 & \\
$W A C C$ & -0.24328 & 1 \\
\hline
\end{tabular}

In the other test conducted in this study, the correlation was negative also between the cost of capital and the share prices for the same companies as indicated in Table IV.

TABLE IV: WACC \& MVS RESULTS

\begin{tabular}{lcc} 
& WACC & MVS \\
\hline WACC & 1 & \\
$M V S$ & -0.11831 & 1 \\
\hline
\end{tabular}

\section{SUMMARY AND CONCLUSION}

This study examined the degree of correlation in Kuwait stock exchange from two perspectives following the Ohlson (1995) basic equity valuation model. The first test was conducted between the cost of capital and the book value after adjusting the abnormal earnings. While the second test is between share prices and cost of capital for each firm for the period between 2005 and 2011.

Results indicated that there is a negative correlation for the book values and the share prices when tested against the cost of capital for the sample of companies used in this test. Hence, it is logically expected that some listed companies on KSE to be liquidated in the near future or at least to get out of the KSE market. The reason behind this is the gap between the cost of capital, book values, and market values. In other words, they are moving with different directions. This would be due to the misallocation or the distribution of the company's capital structure which is definitely need to be reengineered before these companies find themselves out of the market.

Hence, Ohlson (1995) model is considered an advanced and improved model as it relates the stock price to its book value and cost of capital. Therefore, it gives a clear view on the company financial situation and its ability to continue in the market based on its current capital structure and its stock performance in the market. Moreover, it shows if the company needs to make some changes in its capital structure at least to ensure the minimum returns for its shareholders.

\section{REFERENCES}

[1] Dechow et al., "An empirical assessment of the residual income valuation model," Journal of Accounting and Economics, vol. 26, pp. 1-34, 1999.

[2] R. J. Lundholm, "A tutorial on the Ohlson and Feltham/Ohlson models: Answers to some frequently asked questions," Contemporary Accounting Research, vol. 11, pp. 749-761, 1995.

[3] V. Bernard, "The Feltham-Ohlson framework: Implications for empiricists," Contemporary Accounting Research, vol. 11, pp. 733-747, 1995.

[4] R. Frankel and C. M. C. Lee, "Accounting valuation, market expectation, and cross-sectional stock returns," Journal of Accounting and Economics, 1998

[5] R. Brief and P. Zarowin, "The value relevance of dividends, book value and earnings," Department of Accounting, New York University, no. 99-3, 1999.

[6] M. Crae and H. Nilsson, "The explanatory and predictive power of different specifications of the Ohlson (1995) valuation models," The European Accounting Review, vol. 10, no. 2, pp. 315-341, 2001.

[7] Y. Choi et al., "Linear information models in residual income based valuation: A development of the Dechow, Hutton and Sloan empirical approach," Lancaster University, 2001.

[8] J. L. Callen et al., "Accounting restatements: Are they always bad news?" University of Toronto, 2001. 
[9] H. Woldegabir, "Unpublished masters of commerce research report," University of Cape Town, Johannesburg, South Africa, 2004.

[10] V. Khodadadi et al., "Design of linear information model in Tehran stock exchange: Expansion of Ohlson model," Tehran University, 2005.

[11] D. Vazquez et al., "Value relevance of the Ohlson model with Mexican data," Universidad Nacional Autonma de Mexico, 1997.

[12] F. Dahmash and M. Qabajeh "Value relevance of Ohlson model with Jordanian data," Interdisciplinary Journal of Contemporary Research in Business, vol. 3, no. 11, pp. 551-560, 2012.

[13] R. D. Vazquez, A. L. Valdes, and H. V. Valdes, "Value relevance of the Ohlson model with Mexican data," Universidad Nacional Autonma de Mexico, 2007.

[14] R. C. Graham and R. D. King, "Accounting practices and the market valuation of accounting numbers: Evidence from Indonesia, Korea, Malaysia, the Philippines, Taiwan, and Thailand," International Journal of Accounting, vol. 35, no. 4, pp. 445-470, 2000.

[15] M. Collins and Weiss, "Changes in the value-relevance of earnings and book values over the past forty years," Journal of Accounting and Economics, vol. 28, pp. 83-115, 1997.

[16] F. Pariente, "Revisiting Ohlson's equity valuation model," Université Paris IX Dauphine, 2003

[17] J. Myers, "Implementing residual income valuation with linear information dynamics," The Accounting Review, vol. 74, pp. 1-28, 1999.

[18] J. Abarbanell and V. Bernard, "Is the U.S. stock market myopic?" Journal of Accounting Research, vol. 38, pp. 221-242, 2000.

[19] R. Brealy, A. Marcus, and S. Myers, Fundamentals of Corporate Finance, New York: McGraw-Hill/Irwin, 2007.

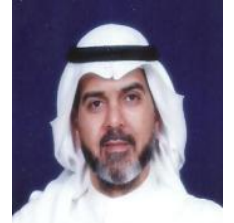

Wael E. Al-Rashed received his Ph.D in accounting from University of Hull (UK) and his Master degree in Accounting and Finance from University of Scranton (USA). Prof. Al-Rashed has more than 30 years of academic and professional experience with many articles/Books/ Monographs publications. In addition, he presented his research in different international conferences and supervised many Master and doctoral studies. Prof. Al-Rashed is currently lecturing at the College of Business Administration-Kuwait University.

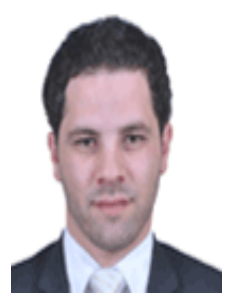

Mohamad H. Atyeh received his Ph.D in business administration (Finance) from Jinan University (Lebanon) and his Master degree in Finance from University of Western Sydney (Australia) in addition to the CVA and CWM professional designations. Dr. Atyeh served on the board of three companies specialized in oil, media and financial management and has more than ten years of professional experience. Before joining the Australian College of Kuwait (ACK) he was heading the corporate finance and investment advisory department at a holding investment group and a lecturer at the Institute of Banking Studies, Kuwait. Dr. Atyeh presented his research in international conferences such as USA, Australia and Turkey and has several scientific publications in different journals focusing on the corporate finance and financial integration fields. 